right side, - the two symptoms just mentioned not being manifest till the second or third day, - and considerable stupor and pain in the head, after reduction had eased the pain in the hip. In the medical treatment of this case I was assisted by Dr. Ware, and its result was equally fortunate with the other. The treatment was similar to the last as regards the administration of croton oil, but in this case it was thought best to have recourse to venesection, when reaction had fully taken place, and also on the third day; because the patient had lost but little blood from the accident, and reaction was more violent than in the former case. He was also blistered on the nape of the neck about a week after the accident, a considerable abrasion on the back of the shoulder, which had discharged a good deal, having nearly healed at the time. A mercurial was also given several times, when the secretion of the liver was deficient. It is now six weeks since the accident, and the patient is able to walk out, with the assistance of a caue, though the strabismus and distortion of the face still remain. I will now close, and leave further comment to those more experienced than a young surgeon located in a Canadian village, merely adding that from my humble experience of the diurnal administration of croton oil, I accord in opinion with Dr. Fife as to its perfect safety. September, 1857.

\section{PARASTTICAL DISEASES AS INFLUENCED BY COOKING.}

BY B. DANIEL, Esq., M.R.C.S.E., L.S.A., Chelsea.

Ir has appeared to be a subject of scarcely less vital importance than wilful adulteration, that attention should be concentred on the innumerable parasitical animals which have been found to infest all parts of organised animals ; for microscopical researches have of late years pretty clearly shown that the larvæ of one species of parasitical insect, when introduced into the body, will give rise to the development, in different parts of the system, of parasitical creatures modified in their organisms and structures according to the particular dwellings assigned to them. It has been shown by direct experiment that cysticerci, the insects which constitute measled pork, are capable of being transformed into tæniæ when introduced into the alimentary passages of sheep, of dogs, or of rabbits. An experiment has been made on the body of a criminal, and anthenticated by indisputable evidence, which has proved by ocular demonstration, after death, the existence of young tæniæ (tænia solium) in the duodenum and the small intestines, resulting from the administration of cysticerci during life. It has also been shown that coenures, ${ }^{*}$ by their presence and accumulation in the brain and spinal cord of sheep, produce pres. sure on those organs and cause vertigo in them, popularly designated as the "staggers." These cænures are said, by some observers, to be convertible into the cysticerci of pork, and to be also capable of developing themselves into tæniæ.

There is a strong tendency in recent observations to establish a theory that development of parasitical animals is determined by the particular medinm which they inhabit; that, in the highest state of development, the same species of larvæ which develope themselves into tæniæ, lumbricoides, or ascarides, in the intestines, may in other parts of the body be converted into hydatids and acephalocysts of all sorts; that, also, the larvæ of the higher-developed creatures can undergo a retrogressive process, and that ova of tapeworm are thus convertible into cysticerci.

In investigations into the microscopic world, observers are lost in wonder at the small beginnings of animated nature. Infusoria originate in an unaccountable manner. If we boil dried juice of cabbage in distilled water, in a few days glau comæ are found; creatures capable of locomotion, with a slit for a mouth, and multiplying themselves by subdivision and germination. There are minute parasitical bodies which tax the ingenuity of the most learned, patient, and practised observers to determine to what kingdom they belong, whether animal or vegetable, or whether, as in the particular instance

* There is a peculiar metamorphosis of the cyst of the cysticercus, which, in some cireumstances, acquires the faculty of putting forth buds on its surface, which develop themselves, and thus form a colony of cysticerci implanted Rod. Leuckart, "Du Parasitisme et des Purasites," in Archiv. für Pbysiol., Heilkunde, 1852.) of intestinal worms, they are, as Henle observes, "a link in the series of development of helminthes." It does not appear an extravagant idea that the germs of disorders in the animal constitution may have their origin in the introduction of these infinitesimal organisms into the body. In the instance of cholera, London experience has shown how much it is influenced by the quality of water supplied to its inhabitants, and much of this water is full of animal and vegetable organisms. It remains to be shown how much of disease may be attributable to the quality of food supplied, - how many cysticerci may be contained in pork sausages, - how many trichinæ spirales in the flesh of birds and beasts, - and how many other abominanations are unwittingly consumed by an innocent public.

To prove that if one animal feed upon another infested by parasitical insects it becomes a prey to the same parasites in its turn, I would give the following experience, taken from No. III. of the Quarterly Journal of Microscopical Science, $1853:-$

"M. Herbst, in 'Fxperiments on the Transmission of Intestinal Worms,' had fed a female badger on vegetables and remains of animals which he had dissected. It died at two years old, and an infinite number of trichinæ were found in all the voluntary muscles.

"The flesh of the badger was given to some young dogs about six weeks old, and was devoured by them in the course of a few days. One of the puppies was sent into the country, and allowed to be at large, exposed to all the usual external influences. On the examination of the other two, made on the 10 th and 18th of February, 1851, all the voluntary muscles were found to be as abundantly infested with the trichinæ as were those of the badger which the puppies had devoured three months before." The third dog, which had been sent into the country, was not examined until nine months after, and although apparently healthy and vigorous, it was found, on a microscopic examination of the sterno-mastoid muscle, that there were innumerable cysts of these trichina. The author expresses his inability to account for the transmission of the ova of these animalcules through the current of the blood into the tissues, which he supposes to take place from the uniform distribution of the insects through the muscles of the voluntary system.

With respect to cysticerci, I should wish to draw attention to "Notes of a Microscopical Examination of 'Measled' and other Pork," by Wm. Smith, F.L.S., Professor of Natural History, Queen's College, Cork, published in the number for October, 1856, of the Micrascopical Journal previously quoted.

In a commercial community, whatever touches the pocket is sure to receive its due meed of scientific investigation. In the south of Ireland, the leading article of commerce is pickled pork, which is supplied largely to Government and to the mercantile marine. 'The presence of "measles" in pork depreciates its quality as an article of food, and necessarily reduces its commercial value-" the market-price is lowered," ergo, "an attempt was lately made by the provision merchants of Cork to arrive at more certain conclusions respecting the nature and extent of the disease, and its precise influence on the character and condition of the flesh affected by it." Mr. Smith observes: "Nineteen specimens were supplied to me--viz.,

6 of healthy fresh pork from various parts of different pigs;

6 of fresh muscle, 'slightly measled;'

6 of fresh muscle, 'badly measled ;'

1 of cured pork, "badly measled."'

And his conclusions are, that the disease of measled pork is owing to the presence of the "cysticercus cellulosæ," an insect contained in a rugose membrane, forming a bag or cyst, which, if inflated, extends to the size of one-third of an inch. The cyst contains the insect, which, coiled up, measures, on an average, one tenth of an inch. These cysts are imbedded between the fasciculi of the muscle, and, collapsing after the death of the pig, give the measly flesh a flabby appearance. The animal is described as consisting of " a slightly enlarged head, and a neck formed of numerous rings, gradually enlarged into a bladder-like vesicle, which constitutes the body of the worm." "The head of the cysticercus is provided at its extremity with a circlet of abont twenty-four hooklets, immediately beneath which are situated four circular organs." The hooklets, when farther magnified, present a stem fixed in the flesh of the head, a barb, and a sickle-like point. Mr. Smith agrees with most of the eminent physiologists of the present day, that the cysticerous of the pig is the "scolex"- that is, the intermediate or arrested condition of the tænia solium or tapeworm of man or other mammalia, and that the experiments made on dogs or other quadrupeds place the fact beyond a doubt. He concludes by saying, that "no 
apprehension need be entertained of tapeworm following the use of measled pork, provided the flesh be carefully curcd or thoroughly cooked." **

A passing allusion to some of the experiments performed by M. Kuichenmeister, and recorded in the "Comptes rendus cles Séances de l'Académie des Sciences, 17 A vril, 1854," may give additional force to the necessity of rigorous attention to the preparation of food.

One of these experiments showed that the administration to dogs of the flesh of rabbits infested with cysticerci produced the following effects:- When these dogs were opened a fow hours after their repast, it was found that the cysts had broken, and that the worm had arrived in the small intestines, to the lining membrane of which it had attached itself by its system of hooklets. In its new habitation the cysticercus loses its globular form; it becomes cestoid, and elongates itself rapidly. Another experiment enabled M. Kuichenmeister to produce tænixe of all sizes and ages, by similar means of administering infected flesh of rabbits to dogs. He also administered to a young and healthy sheep the ova of tæniæ, and produced the presence of "cenures" in the brain, artificially causing the disease of sheep, "staggers." Conversely, by the exhibition of the cænures found in a diseased sheep's brain, he succeeded in effecting the production of trenia in dogs. By a series of patient observations he also traced the embryogenesis of these creatures in numbers of diseased sheep's brains, and found that it consisted in a gemmation on the surface of the matricular cell, and which detached itself on arriving at an independent organization. The history of these vesicular worms is one of the most mysterious problems in modern zoology. They are now generally regarded as a species of larva, or rather as nutricest- the term used by the great microscopist and zoologist, Steenstrup. A great many important questions rest with the exposition of this mysterious "alternation of generations," as it has been called. There is the question of spontaneous generation, the wonderful production of myriads of animalcules wherever disorganized vegetable or animal matter exists. Whence come the unicellular gregarina and the diatomacex, which have puzzled naturalists to account them either animal or vegetable? and whither do they tend? If this transition of animalcules which is said to take place-e. g., gregarina into filaria, and cysticerci into tæniæ-be established, it will go far to prove that the simple organized cell may be the parent of all animated nature, as it is proved to be the parent of all the tissues of our bodies.

The following experiment by Kiichenmeister, reported in the "Wiener Mediz. Wochenschrift," No. 1,1855 , shows the generation of trenia solium resulting from administration of cysticerci to a criminal condemned to decapitation:-During 130 hours preceding his execution, he had given to him, at different intervals, 75 cellular cysticerci, which had been exposed to the air, and were administered in patés, in vermicelli, in sausages, and in pudding. The autopsy took place 48 hours after death, in the presence of numerous professors. In the duodenum, attached to the mucons membrane by its elongated trunk, was observed by all present a young trenia. The portion of mucous membrane was removed, with the insect attached, and placed under the microscope. Its trunk, with four hooklets projecting, were distinctly observed. Three other tæuiæ were also found with hooklets varying in number, with one pair, two pair, and with a complete circle of twenty-two hooklets. Others were found in the water in which the intestines had been washed. The conclusions drawn by M. Kitchenmeister are-1. That cellular cysticerci are converted, in man, into tænia solium. 2. That treniæ arise either from their own ova or from cysticerci. 3. That tænia solinm is contracted by eating cysticerci, either in raw food or administered in cooked cold food.

It is a singular observation of M. Wawruch ("CEsterreich Mediz. Jahrbicher," 1841, No. 2), that tænia are not to be found amongst the Jews. Of 206 cases observed by him, it was found it all ages, from three to fifty-five, but more frequently in adults. With regard to sex, there were 135 females to 71 males. In respect of occupations, there were 1 male cook, 52 female cooks, several butchers, and 11 gluttonous eaters of meat.

* In the healthy specimens of pork no cysticerei were found.

+ To designate certain larve which propagate themselves as such without sexual conjugation, but are, nevertheless, capable of arriving at a sexual development, and of then propagating themselves by ova. The head of tenia solium is placed in this category; it never directly produces ova, lrut first one joint, then another intermediate between itself and the first, and so on. 'Thus the first-formed joints becorne the tail. These eventually contain ova, and are thus converted into generating larvæ. (See Rod. Teuckart, "Du Parasitisme et des Parasites," in Archiv. für Physiol., Hcilkunde, 1852.)
Taking all these matters into consideration, it certainly does appear that insufficient discrimination cxists amongst the modern populations of towns in the selection of their food. Due weight is not given to the important bearings which the quality of food exerts upon the diseases and physical consti. tution of the people. Ancient civilization--Egyptian, Jowish Findoo, Mahomedan, Greek, and Toman, have all had their restrictions and sanitary regulations for the selection and pre. paration of food. The Egyptians-sensible people in their way-had no faith in medicine beyond a vomit, a purge, a bath, or a fist. All diseases were attributed to the food they ate, and they were consequently very particular, especially as abstinence from certain forbidden meats was enjoined as a sacred religious obligation. It does appear that they were deprived of much good and digestible food. The Egyptians could not have legs of mutton, because of their god, Ammon, whom they worshipped as a ram. The modern Jews neither eat sirloin of beef or rumpsteaks; they eat not hind-quarters of animals, because of the wrestlings which Jacob had with the angel, who "touched the hollow of his thigh, and the hollow of Jacob's thigh was out of joint as he wrestled with him." Thus some restrictions are purely ceremonial, while others are sanitary. After the exposé which has been made of the diffe. rent abominations which exist in meats, and which may be said to be thus adulterated by natural causes, it is a consolation to know that all these germs of disease can be destroyed by thorongh cooking, either boiling, roasting, or broiling. Par. ticular care ought to be given to pork-sausages that they be well done. All other meats should be equally well cooked. By so doing, it is asserted, that diseased meats may be eaten with impunity. In cholera times, drinking water should be previously boiled. Flourens reports that in 1789 the people of the Faubourg St. Germain and Di Alfort ate with impunity carcases of horses diseased with glanders and farcy; that in 1814,1815 , and 1816, animals died of contagious fevers and were eaten; whilst cows affected with pulmonary phthisis are being constantly consumed in the market without ill consequences. M. Renanlt has published a memoir in which he asserts, that notwithst: nding all our natural antipathies, we may safely partake of diseased cows, oxen, sheep, fowls, \&c., and may totally disregard what they may have been fed upon, providing they are thoroughly cooked. Without going the whole length of these conclusions, we must agree that a high temperature necessarily destroys organic life, and may so alter the fibrinons, purulent, or albuminous products of disease as to render them innocuous.

I must conclude this communication, by recommending thorough cooking of their victuals to the poor as one of the best safeguards that they can use against the impositions to which their poverty exposes them. It is a simple, practical, and cheap antidote to the filth so frequently sold under the name of food.

Cheisen, October, 1857.

Decoratron of the Museun at St. Bartholonew's Hosprrat. - Mr. Owen Jones exercising his decorative art in Smithfield sounds oddly; but it is a fact. They who remember the old museum at St. Bartholomew's, have in their mind's eye a dull, dingy, dreary room, the drabby colour of which so assorted with the hue of the objects, bones, skeletons, and "preparations" generally there preserved, that it was difficult to distinguish one from the other. Mr. Owen Jones was sum. moned, and he has effectually "changé tout cela." The musenm has now a light, airy, and lieal thy look. It is a saloon instead of a cell. The portion of the roof that is not of glass is tastefully painted in squares, the central white of which is occupied by one of those graceful ornaments, neither star nor circle, which the artists can more ensily throw off than the critic can describe. The scroll, running beneath the roof and the upper gallery, is exquisitely decigned and executed. The flooring of the upper gallery is of glass, so that the gallery beneath is deprived of little or no light. The arm-rail of the lower gallery is covered with crimson velvet, and the walls are of a rich, warm maroon colour, against which the pale-coloured objects, relics or copies of suffering mortality, stand out in the boldest possible relief. It is strprising to mark what great effects may be produced by a few colours applied by an artistic hand obey. ing the inspirations of a discerning mind. The change is greatly appreciated, no doubt, by the students and their instructors; and old Rahere, the joyous founder of St. Bartholomew's Hospital, might look with approving complacency on the results of the skill and good taste of Mr. Owen Jones.-The A thenceum. 